\title{
Evaluation of Histopathological Changes and Enzyme Bioassay during Interaction between Verticillium fungicola and Agaricus bisporus
}

\author{
Jagdeep Singh*, Surjeet Singh, Manoj Kumar, Anil Kumar and Rakesh Kumar \\ Department of Plant Pathology, College of Agriculture, Chaudhary Charan Singh \\ Haryana Agricultural University, Hisar-125004, Haryana, India \\ *Corresponding author
}

\section{A B S T R A C T}

\begin{tabular}{|l|}
\hline Ke y w o r d s \\
Verticillium fungicola, \\
Agaricus bisporus, \\
Enzyme, Interaction, \\
Histopathology. \\
\hline Article Info \\
\hline $\begin{array}{l}\text { Accepted: } \\
\text { 28 September } 2017 \\
\text { Available Online: } \\
\text { 10 November } 2017\end{array}$ \\
\hline
\end{tabular}

\section{Keywords}

Verticillium fungicola Agaricus bisporus,

Enzyme, Interaction,

10 November 2017
Verticillium fungicola var. fungicola (Preuss) is the most important dry bubble disease causing pathogen of the Agaricus bisporus (Lange) Imbach. Therefore, present investigation carried out on $A$. bisporus host and $V$. fungicola pathogen; by covering an aspect of interaction, variability and management of Verticillium dry bubble disease in India. Host and pathogen easily distinguishable at interaction regions on the basis of hyphal width i.e. ranged from 4.0 to $6.5 \mu \mathrm{m}$ and 1.5 to 4.5 $\mu \mathrm{m}$ respectively. Pathogen grow inter and interacellularly on host hyphae and resulting in damaged, coiling and lysis of host mycelia. During enzymatic bioassay in dual culture on inducing substrate and mushroom extracts, mycopathogen showed the production of different hydrolytic enzymes i.e. amylase, cellulose and chitinase but not lipase and pectinase by formation of clear zonation on substrate.

\section{Introduction}

The commercial production of edible mushroom converts different types of agricultural and household wastes into nutrition rich food which helps in addressing the problems of quality food, health and environmental sustainability. In view of increasing demand of high quality food with an increasing world population, mushrooms will be an important source of proteins that can replace meat and vegetables and milk products for a major part (Wani et al., 2010). About 1.5 million species of fungus are known (Hawksworth, 1991) and out of these it has been estimated that 14,000 species produce fruiting bodies that are desirable to be considered as mushrooms (Hawksworth, 2001). About 7,000 species of edible mushrooms are known out of which 200 are experimentally grown and 10 have been produced at the industrial scale (Chang and Miles, 2004). In India, mostly four species of edible mushrooms viz., Agaricus bisporus (white button mushroom), Volvariella spp. (paddy straw mushroom), Pleurotus spp. (oyster mushroom) and Calocybe indica (milky mushroom) are commercially cultivated.

Mushroom cultivation is affected by a large number of biotic and abiotic factors. Fungi, 
bacteria, viruses, nematodes, insects and mites are different biotic factors that damage the mushroom crop directly or indirectly (Sharma et al., 2011). Among the various factors responsible for low production and productivity of mushroom in our country, fungal diseases play a major role. The fungal pathogens, Verticillium fungicola, Mycogone perniciosa, Trichoderma spp. and Papulaspora byssina are the predominant mycopathogens. Amongst these, Verticillium fungicola var. fungicola (Preuss) is the important pathogen of the Agaricus bisporus (Lange) Imbach and annual losses to the growers are estimated to be $2-4 \%$ of total revenue (Berendsen et al., 2010). The pathogen induces various symptoms like bubbles (undifferentiated spherical masses), bent and/or split stipes (blowout) and spotty caps. Inoculation of $A$. bisporus crop with isolates of $V$. fungicola var. fungicola of various degrees of aggressiveness showed that the more aggressive isolates induced higher numbers of bubbles (Largeteau and Savoie, 2008). The Verticillium dry bubble is the most prevalent disease and if left uncontrolled in the mushroom growing environment; the disease can wipe out an entire crop in 2-3 weeks (Sharma et al., 2002). Moreover, the disease may be devastating for years following the initial infection because spores are capable of resting in debris and reinfecting crop year after year (Berendsen et al., 2010).

\section{Materials and Methods}

By dual culture method hyphal interactions between $A$. bisporus and $V$. fungicola were studied by growing five mm mycelia disk cut from actively growing colonies of both fungi and were placed six $\mathrm{cm}$ apart on the surface of $2 \%$ PDA in Petri plates and $0.2 \%$ PDA on a clean and sterile glass microscope slide and incubated both at $25 \pm 1{ }^{\circ} \mathrm{C}$ for nine days. The antagonist grew radially and overgrowth of $A$. bisporus by $V$. fungicola began to occur by 5 to 7 days after inoculation. Mycelial samples from the interaction region in Petri plates were excised along with agar media and in case of glass microscope slide the mycelia at point of interaction directly examined and each one stained with methylene blue during examination. These samples were examined under high power objective of optical research compound microscope (40X). Records of the interactions between opposing colonies including hyphal width, contact or coiling were made after incubation. After one week, the slides were examined microscopically for lysis of A. bisporus mycelium by $V$. fungicola. Extracellular enzymes (viz. amylase, cellulase and chitinase) bioassays of pathogen during $V$. fungicola and A. bisporus interaction as per methods of Cattelan et al., (1999) and Lima et al., (1993). Fungal enzymes play an important role in host infection since they can localize on host structures to develop infection and eventually leading to disease. Hence, the qualitative bioassay was performed to estimate the presence of extracellular enzymes i.e. amylase, cellulose, chitinase, lipase and pectinase during interaction of $V$. fungicola and A. bisporus in dual culture.

\section{Results and Discussion}

\section{Mode of parasitism under microscope}

Hyphal interactions (Plate-1): the mycelia samples taken from the interaction zone of dual cultures in Potato dextrose agar. The hyphae of $V$. fungicola and $A$. bisporus in individual as well as in paired cultures could be readily distinguished on the basis of hyphal width. The hyphal width of host ranged from $4.0-6.5 \mu \mathrm{m}$ while mycopathogen ranged from 1.5-4.5 $\mu \mathrm{m}$. Therefore, different hyphal width of both easily distinguish under interaction study and at interaction point host mycelium damaged and pathogen grow in and on 
hyphae of host and coiling and lysis of host hyphae were also reported after two weeks of incubation.

During interactions studies the host and pathogen easily distinguish and at interaction point host mycelium damaged and pathogen grow in and on hyphae of host and coiling and lysis of host hyphae were also reported after two weeks of incubation. These findings are in complete agreement with Pieterse (2005) and Sabharwal et al., (2014) that depicted the clear difference in hyphal diameter of host and pathogens and easily distinguishing the two under interaction studies. Similarly, Dragt et al., (1996) showed that hyphae of the mycopathogen coil around the host hyphae with firm adhesions but intra-hyphal growth can also be observed in dry bubble pathogen Verticillium fungicola var. fungicola.

Table.1 Enzymatic bioassay during interaction of Agaricus bisporus and Verticillium fungicola

\begin{tabular}{|c|c|c|c|c|c|}
\hline \multirow{2}{*}{$\begin{array}{l}\text { Sr. } \\
\text { No. }\end{array}$} & \multicolumn{5}{|c|}{ Enzymatic activity *bioassay during host and pathogen interaction } \\
\hline & $\begin{array}{l}\text { Name of } \\
\text { enzymes }\end{array}$ & $\begin{array}{l}\text { Activity inducer } \\
\text { medium }\end{array}$ & $\begin{array}{l}\text { Agaricus } \\
\text { bisporus }\end{array}$ & $\begin{array}{l}\text { Verticillium } \\
\text { fungicola }\end{array}$ & Both \\
\hline \multirow{2}{*}{1} & \multirow{2}{*}{ Amylase } & Substrate & + & + & + \\
\hline & & Mushroom extract & - & + & + \\
\hline \multirow{2}{*}{2} & \multirow{2}{*}{ Cellulase } & Substrate & + & + & + \\
\hline & & Mushroom extract & - & + & + \\
\hline \multirow{2}{*}{3} & \multirow{2}{*}{ Chitinase } & Substrate & - & + & + \\
\hline & & Mushroom extract & - & + & + \\
\hline \multirow{2}{*}{4} & \multirow{2}{*}{ Lipase } & Substrate & - & - & - \\
\hline & & Mushroom extract & - & - & - \\
\hline \multirow{2}{*}{5} & \multirow{2}{*}{ Pectinase } & Substrate & - & - & - \\
\hline & & Mushroom extract & - & - & - \\
\hline
\end{tabular}

*Average of three replications, Where + : zone (enzyme activity) present and - : zone (enzyme activity) absent

MICROSCOPICALLY EXAMINATION OF INTERACTION

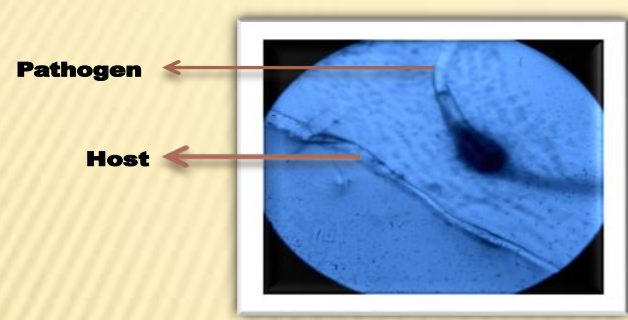

A- Fungal hyphae

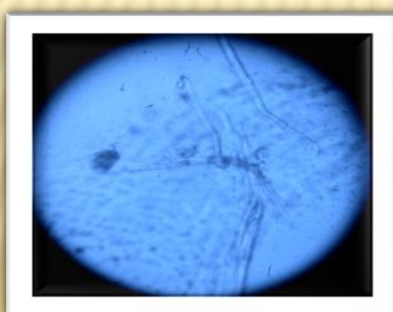

C- Hyphal coiling

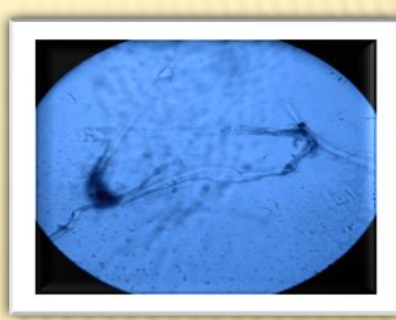

B-Hyphal contact

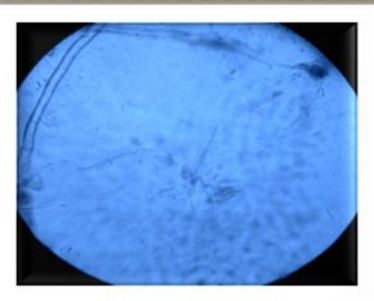

D- Hyphal lysis 
Plate.1

\section{HYPHAL INTERACTION IN DUAL CULTURE}

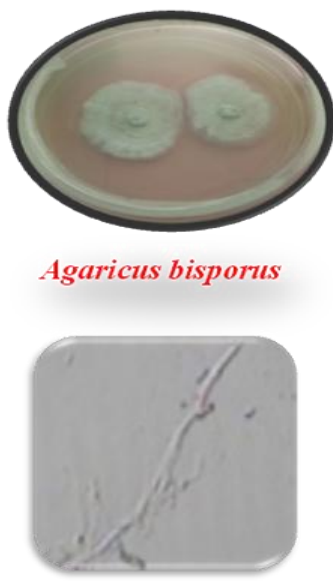

A- Host

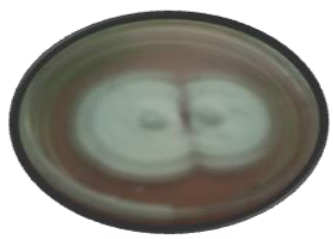

Verticillium fungicola

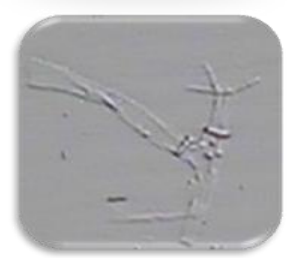

B-Pathogen

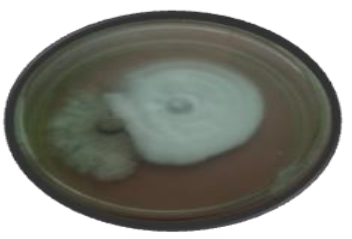

Both

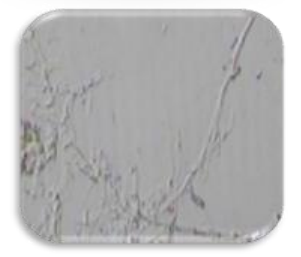

C- Interaction

\section{Extracellular enzymes bioassays}

V. fungicola screened for its extracellular enzymes bioassay (Table-1) like amylase, cellulose, chitinase, lipase and pectinase activity by plate assay method during hostpathogen interaction. The qualitative assessment of mycopathogen singly as well as in dual culture on enzymatic activity inducer medium substrate and mushroom extracts showed the production of different hydrolytic enzymes i.e. amylase, cellulose and chitinase but not lipase and pectinase. V. fungicola singly as well as in dual culture showed the clear zonation on substrate and mushroom extract which are due to enzymatic activity of amylase, cellulose and chitinase while, rest one (lipase and pectinase) no any zonation are reported. The qualitative assessment of mycopathogen singly as well as in dual culture on enzymatic activity inducer medium substrate and mushroom extracts showed the production of different hydrolytic enzymes i.e. amylase, cellulose and chitinase but not lipase and pectinase. Therefore, we considered that the disintegration of host hyphae due to enzymatic activity of mycopathogen. Similarly, Mills et al., (2008) confirmed that $V$. fungicola produced a wide range of hydrolytic enzymes, which play a critical role in the infection process. On the other hand, Trigiano and Fergus, (1979) reported that $V$. fungicola is able to produce extracellular enzymes such as an amylase, lipase and cellulose.

During interactions studies the host and pathogen easily distinguish and at interaction point host mycelium damaged and pathogen grow in and on hyphae of host and coiling and lysis of host hyphae were also reported after two weeks of incubation. $V$. fungicola in dual culture showed the clear zonation on substrate and mushroom extract which are due to enzymatic activity of amylase, cellulose and chitinase.

Therefore present studies concluded in single pharos, it revealed that dry bubble disease of button mushroom was caused by $V$. fungicola due to producing various enzymes during interaction process and caused coiling and disintegration of host hyphae which leads to symptoms development. 


\section{References}

Berendsen, R.L., Baars, J.P.P., Kalkhove, S.I.C., Lugones, L.G., Wosten, H.A.B. and Bakker, P.A.H.M. (2010). Verticillium fungicola: causal agent of dry bubble disease in white-button mushroom. Mol. Pl. Pathol., 11: 585-595

Cattelan, A.J., Hartel, P.G. and Fuhrmann, J.J. (1999). Bacterial composition in the rhizosphere of nodulating and nonnodulating soybean. Soil Sci., 62: 15491555.

Chang, S.T. and Miles, P.G. (2004). Mushrooms: Cultivation, Nutritional Value, Medicinal effect and Environmental Impact (2nd edition). Boca Raton, CRC press. pp 6.

Dragt, J.W., Geels, F.P., De Bruijn, W.C. and Van Griensven, L.J.L.D. (1996). Intracellular infection of the cultivated mushroom Agaricus bisporus by the mycoparasite Verticillium. Mycol. Res., 100: 1082-1086.

Hawksworth, D.L. (1991). The fungal dimension of biodiversity: magnitude, significance and conservation. Mycol. Res., 95: 641-655.

Hawksworth, D.L. (2001). Mushrooms: the extent of the unexplored potential. Int. J. Med. Mush., 3: 333-337.

Largeteau, M.L. and Savoie, J.M. (2008). Effect of the fungal pathogen Verticillium fungicola on fruiting initiation of its host, Agaricus bisporus. Mycol. Res. 112: 825-828.

Lima, E.O., Gompertz, O.F., Giesbrecht, A.M. and Paulo, M.Q. (1993). In vitro antifungal activity of essential oils obtained from officinal plants against dermatophytes. Mycos., 36: 333-336.

Mills, P., Thomas, J., Sergeant, M., Costa, A., Collopy, P., Bailey, A., Foster, G. and Challen, M. (2008). Interaction between Agaricus bisporus and the Pathogen Verticillium fungicola. In: Stress un Yeasts and Filamentous Fungi. Avery S.V., Stratford M. and Van West P. (Eds.). pp. 1-18. The British Mycology Society.

Pieterse, Z. (2005). Mycogone perniciosa, a pathogen of Agaricus bisporus. M.Sc. thesis, University of Pretoria, pp. 1-38.

Sabharwal, A. and Kapoor, S. (2014). In vitro effect of essential oils on mushroom pathogen Mycogone perniciosa causal agent of Wet Bubble Disease of White Button Mushroom. Indian J. Appli. Res., 4: 482-484

Sharma, S.R., Satish, K., and Sharma, V.P. (2002). Diseases and Competitor Moulds of Mushrooms and their Management. J. Early Repub., 22: 509516.

Sharma, V.P., Kumar, S., Kamal, S. and Singh, S.K. (2011). Etiology and molecular characterization of wet bubble disease causing fungus (Hypomysis perniciosus) in Agaricus bisporus. Mush. Res. 20 (1): 21-25.

Trigiano, R.N. and Fergus, C.L. (1979). Extracellular enzymes of some fungi associated with mushroom culture. Mycologia, 71: 908-917.

Wani, B.A., Bodha, R.H. and Wani, A.H. (2010). Nutritional and medicinal importance of mushrooms. J. Med. Pl. Res., 4: 2598-2604.

\section{How to cite this article:}

Jagdeep Singh, Surjeet Singh, Manoj Kumar, Anil Kumar and Rakesh Kumar. 2017. Evaluation of Histopathological Changes and Enzyme Bioassay during Interaction between Verticillium fungicola and Agaricus bisporus. Int.J.Curr.Microbiol.App.Sci. 6(11): 4140-4144. doi: https://doi.org/10.20546/ijcmas.2017.611.485 